\title{
Human Clinical Subject Data Section
}

National Cancer Institute

\section{Source}

National Cancer Institute. Human Clinical Subject Data Section. NCI Thesaurus. Code C105754.

A section within the study document pertaining to data collected from human clinical study subjects. 